\title{
Chinese Economic Presence in Kazakhstan
}

China's Resolve and Central Asia's Apprehension

\section{Sébastien Peyrouse}

\section{(2) OpenEdition}

\section{Journals}

Electronic version

URL: http://journals.openedition.org/chinaperspectives/4053

DOI: $10.4000 /$ chinaperspectives.4053

ISSN: 1996-4617

\section{Publisher}

Centre d'étude français sur la Chine contemporaine

\section{Printed version}

Date of publication: 1 July 2008

Number of pages: $34-49$

ISSN: 2070-3449

\section{Electronic reference}

Sébastien Peyrouse, "Chinese Economic Presence in Kazakhstan », China Perspectives [Online] 2008/3 | 2008, Online since 01 July 2011, connection on 28 October 2019. URL : http://

journals.openedition.org/chinaperspectives/4053; DOI : 10.4000/chinaperspectives.4053

(C) All rights reserved 
L

\title{
Chinese Economic Presence
} in Kazakhstan

\author{
China's Resolve and Central Asia's Apprehension
}

SÉBASTIEN PEYROUSE

In the course of only a decade, Kazakhstan has become China's second biggest partner behind Russia in the postSoviet space. Economic relations between Astana and Beijing are characterised by a considerable imbalance of power that is of concern in some political and expert circles in Kazakhstan, while the tremendous opportunity for development offered by China's proximity brings hope that the country might be extricated from the crisis that followed the dissolution of the Soviet Union.

$\mathrm{T}$ he collapse of the Soviet Union in 1991 enabled the states of Central Asia to rediscover their Chinese neighbour, excluded from the economic and cultural reality of the region during the years of Sino-Soviet conflict. In less than two decades, Beijing has taken advantage of the disappearance of its Soviet neighbour to launch its program of development of the "Great West" and open up Xinjiang to border nations, while the states of Central Asia, seeking new partners, have sought to benefit from China's dynamism by integrating themselves into the Asia-Pacific zone of prosperity. While the Chinese authorities may make a point of honour in establishing cordial relations with the five states of the region, Kazakhstan enjoys a particular status: indeed, the China-Kazakhstan partnership is termed "strategic," the highest of diplomatic epithets, confirming Astana as a major political ally of Beijing in a post-Soviet climate in which the Kazakh government is displaying balanced and diversified policies in the face of Moscow's heavy-handed presence. ${ }^{(1)}$ This privileged China-Kazakhstan partnership is based on a multifaceted economic reality. These days, ChinaKazakhstan trade represents more than two-thirds (about 70 percent) of all China-Central Asia trade. Unlike the other historical power in the region, Islam Karimov's Uzbekistan, Kazakhstan, under the leadership of President Nursultan Nazarbaev since 1989, has undertaken important economic liberalisation reforms that, despite their limitations, are now succeeding in attracting foreign investment. ${ }^{(2)}$ Kazakhstan has thus become the second richest country in the postSoviet space: with a GDP estimated at $\$ 9,400$ per capita in
2006, it sits just behind Russia (with approximately $\$ 12,000$ ) but ahead of the other Central Asian countries (between $\$ 8,500$ and $\$ 1,300$ ). In 15 years, it has succeeded in dramatically halving the portion of its population living below the poverty line (now less than 25 percent), whereas in the other four states of the region, more than half of the population is still considered "poor." In addition, the country has seen the emergence of a middle class, a guarantee of longer-term stability.

The exponential growth in economic relations with China since the beginning of the 1990s has not once been challenged. Kazakhstan even opened a consulate in Hong Kong in 2003 and one in Shanghai in 2005 to facilitate contact. Nevertheless, economic relations between the two countries reveal multiple imbalances that are increasingly raising questions within Kazakhstan's political class and among local experts. While the official Chinese position extols the com-

1. On relations between China and Central Asia, see Thierry Kellner, L'Occident de la Chine, Pékin et la nouvelle Asie centrale (1991-2001) (Western China, Beijing and the new Central Asia [1991-2001]), Paris, PUF, 2007, Thierry Kellner, "La tranquille montée en puissance de la Chine en Asie centrale" (The peaceful rise of China's power in Central Asia), La Revue internationale et stratégique, no. 64, 2007, pp. 143-154, Valérie Niquet, "La Chine et I'Asie centrale" (China and Central Asia), Perspectives chinoises, no. 96, 2006, http://perspectiveschinoises.revues.org/document995.html, consulted 15 August 2008.

2. For an economic evaluation of the region since independence, see Richard Pomfret, The Central Asian Economies since Independence, Princeton-0xford, Princeton University Press, 2006. On the political situation in Central Asia, see Marlène Laruelle, Sébastien Peyrouse, Asie centrale, la dérive autoritaire. Cinq républiques entre héritage soviétique, dictature et islam (Central Asia's drift toward authoritarianism: Five republics between Soviet heritage, dictatorship and Islam), Paris, Autrement-CERI, 2005. 
ernment disagreements often delay their implementation. ${ }^{(8)}$ Several Kazakh specialists also complain of the SCO's inability to promote its economic strategies in business circles; some of its decisions are said to remain declarations of intent due to a lack of information among business leaders. ${ }^{(9)}$ It is difficult to obtain a precise assessment of ChinaKazakhstan trade figures. The official statistics take little account of the extent of cross-border trade, and cannot measure the amount of illegal trade, particularly in metals, ${ }^{(10)}$ or contraband, such as acetic anhydride, the chemical required to turn opium into heroin. ${ }^{(1)}$ Some local specialists point out significant differences between the Chinese and Kazakh statistics. Thus, when Kazakhstan claimed $\$ 550$ million of trade with China in 1999, Beijing was already confirming more than $\$ 1$ billion. In 2005, the discrepancy grew wider: Kazakhstan, according to Astana, apparently achieved imports from China with a total value of $\$ 1.2$ billion, compared to almost $\$ 4$ billion according to Beijing, and Astana reported exports to China worth nearly $\$ 2.5$ billion, exceeding the Chinese figures by more than $\$ 500$ million. ${ }^{(12)}$ The discrepancy can be attributed partly to political reasons: Astana seeks to overvalue its exports and undervalue Chinese imports in order to reduce a trade balance skewed too greatly in China's favour. In 2006, Kazakhstan's trade deficit in relation to its neighbour was at least $\$ 1.14$ billion, 15 percent more than in 2005. ${ }^{(1)}$ On the other hand, the discrepancy can be explained by differences in accounting; Kazakh businessmen have every reason to undervalue their trade flows in order to avoid taxes, unlike their Chinese counterparts, who receive tax concessions on exports. ${ }^{(14)}$

China's progress is so great that Beijing will soon catch up to Kazakhstan's main trade partner, Russia. In 1992, ChinaCentral Asia trade, two-thirds of which is China-Kazakhstan trade, was barely $\$ 422$ million, reaching $\$ 512$ million in 1993. It plummeted in 1994 as a result of stricter visa processes, then rapidly climbed again, reaching $\$ 699$ million in 1997. ${ }^{(15)}$ It experienced a decrease ( $\$ 588$ million) again as a result of the Russian economic crisis of the summer of 1998, which similarly affected Central Asia, then began to grow at a rate that seems unstoppable now. Trade passed $\$ 1$ billion in 2000 before rising tenfold to more than $\$ 10$ billion in 2006. The volume of trade tripled between 2002 and 2005, but continued to largely favour Chinese exports, which represented two thirds compared to Central Asia's one third. Thus, in 2006, China represented 15.5 percent of Kazakhstan's foreign trade (almost $\$ 9$ billion), nearing Russia's 18.8 percent (almost $\$ 11$ billion). ${ }^{(16)}$ China’s Trade Ministry quoted a figure of $\$ 10.8$ billion, which would put
Moscow and Beijing on an equal footing, ${ }^{(17)}$ while Vladimir Paramonov and Aleksei Strokov add another \$2 billion or more in illegal trade, which would give China trade supremacy over Russia. ${ }^{(18)}$ According to Kazakh experts, the bilateral trade figure is expected to reach $\$ 15$ billion in 2008 . ${ }^{(19)}$ The imbalance of power between China and Kazakhstan remains glaringly obvious. In 2006, Kazakhstan represented only 0.49 percent of China's foreign trade (the whole of Central Asia representing 0.60 percent). ${ }^{(20)}$ This imbalance is shifting to foreign investment: in 2005, China injected $\$ 1.2$ billion into the Kazakh economy (82 percent in the hydrocarbon sector and 14 percent in the construction sector), whereas Kazakhstan invested only $\$ 7.6$ million in China. ${ }^{(21)}$ The Chinese and Kazakh economies are, however, proving to be complementary to a large degree. More than 80 percent of China's exports to Kazakhstan are finished consumer items (textiles, shoes, appliances, toys, electronics, spare parts, pharmaceutical products, foodstuffs), while 85 percent of Kazakhstan's exports to China consist of raw materials (petroleum, ferrous and non-ferrous metals). ${ }^{(22)}$ In some sectors such as aluminium, the unidirectional nature of trade flows is impressive: more than 95 percent of Kazakh

8. Gul'den Zholamanova, "0 nekotorykh aspektakh kazakhstansko-kitajskogo ekonomicheskogo sotrudnichestva v ramkakh SHOS: Politologicheskij analiz," op. cit., pp. 27-37.

9. Ibid., p. 30.

10. Railia Mukimdzhanova, Strany Central'noj Azii. Azijatskij vektor vneshnej politiki (The countries of Central Asia: The Asian vehicle of foreign policy), Moscow, Nauchnaja kniga, 2005, $201 \mathrm{pp}$.

11. "Precursor Control on Central Asia's Borders with China," United Nations Office on Drugs and Crime Regional Office for Central Asia, Vienna, no date of publication.

12. "Sindrom Khorgosa?" (The Khorgos syndrome?), Kazakhstanskaja pravda, 27 May 2005, http://www.nomad.su/?a=13-200605290119, consulted 19 August 2008.

13. Information provided on the site of the Embassy of Kazakhstan in China: http://www.kazembchina.org/create/bike/home.jsp?tablename=itemcontent\&iiid=738 6256821857348225\&tableFlag=itemtable, consulted 19 August 2008.

14. Gaël Raballand, Agnès Andrésy, "Why should Trade between Central Asia and China Continue to Expand?," Asia Europe Journal, vol. 5, no. 2, 2007, pp. 235-252.

15. Vladimir Paramonov, Aleksej Strokov, "Ekonomicheskoe prisutstvie Rossii i Kitaja v Central'noj Azii" (The economic presence of Russia and China in Central Asia), Conflict Studies Research Centre, Central Asian Series, 07/12, 2007, p. 4.

16. Ibid., p. 6

17. Ibid., p. 9.

18. Ibid., p. 8 .

19. "Kazakhstan i Kitaj podpisali memorandum o sotrudnichestve" (Kazakhstan and China have signed a memorandum of cooperation), http://www.rosbalt.biz/2008/06/ 24/497067.html, consulted 12 July 2008.

20. Vladimir Paramonov, Aleksej Strokov, "Ekonomicheskoe prisutstvie Rossii i Kitaja v Central'noj Azii," op. cit., p. 6.

21. lida Ashimbaeva, "Dostizhenija i problemy kazakhstansko-kitajskikh ekonomicheskikh otnoshenij," op. cit.

22. Hsiu-Ling Wu, Chien-Hsun Chen, "The Prospects for Regional Economic Integration Between China and the Five Central Asian Countries," Europe-Asia Studies, vol. 56, no. 7, 2004, pp. 1059-1080. 
aluminium exports are destined for China. ${ }^{(23)}$ In metals, in addition to uranium (cf. infra), China is similarly seeking a foothold in the Kazakh gold market. Thus, in 2005, the China National Gold Group Association and the metals venture Kazakhaltyn Mining signed a contract initiating a joint venture for gold mining in Kazakhstan. ${ }^{(24)}$

This structuring of bilateral trade enjoys far from unanimous support: more and more Kazakh experts denounce the compartmentalisation of the national economy into raw materials and the selling off of the country's last processing and agrifood industries. The situation is strongly criticised, for example, by Alida Ashimbaeva, Director of the Institute of the World Market in Almaty, ${ }^{(25)}$ who believes that this situation jeopardises Kazakhstan's economic independence, and by Konstantin Syroezhkin, the main China expert at the Kazakhstan Institute of Strategic Studies, who asserts that "China's economic successes are objectively running contrary to all the economic interests of Central Asia in the sector of industrial processing and to a certain extent in agriculture." (26) Reaching the same conclusion, Vladimir Paramonov, based in Tashkent, maintains that this trend could lead to a major socioeconomic crisis in the region. ${ }^{(27)}$ Meanwhile, the Director of the Risk Assessment Group, Dosym Satpaev, thinks that Astana has no choice other than to abandon all processing industries and specialise solely in hydrocarbons, uranium, hydroelectricity, cereals, and transshipping. ${ }^{(28)}$

\section{Two sensitive areas: "Shuttle trade" and Chinese-Kazakh joint ventures}

The individual and institutional players in China-Kazakhstan trade can be classified into three categories: shuttle trade so-called "suitcase traders" or "shop tourists" - who are involved essentially in border trade; the private entrepreneurs, often Uyghurs and Dungans in the 1990s but these days replaced by the Han, who are setting up in Kazakhstan's most profitable sectors; and the Xinjiang Production and Construction Corps or XPCC (Xinjiang shengchan jianshe bingtuan), which is thought to account for more than one third of China-Central Asia trade. ${ }^{(29)}$ While Chinese trade with the other Central Asian states is dominated by the major state companies (which by virtue of being established in accordance with bilateral agreements signed at the highest level manage to bypass a defective business environment), Kazakhstan, with its economic dynamism, is the Central Asian republic that attracts the most private Chinese trade. However, compared with the countries of Southeast Asia, medium-sized Chinese enterprises are still relatively few on the ground, leaving the Kazakh market open primarily to small individual traders and large state companies. ${ }^{(30)}$

From the outset of economic relations between the two countries, shuttle trade or "shop tourism" has developed, compensating partially for the collapse of the flow of goods from Moscow and enabling the professional redeployment of a whole class of engineers and service industry workers who had become unemployed with the dissolution of the Soviet Union. In the summer of 1991, the first China-Kazakhstan agreement was signed in Kuldzha, encouraging the development of shop tourism: in the following year, approximately 700,000 Kazakh citizens crossed the Chinese border to buy common consumer items in China with the intention of reselling them back home. ${ }^{(31)}$ In 2002, shop tourism reportedly still provided employment for nearly half a million Kazakhs, who are estimated to have spent more than $\$ 1$ billion in Xinjiang between 1989 and 2003. ${ }^{(32)}$ These increasingly structured and organised "shop tours" (with specialised tourist agencies, Russian-Chinese translation services, hotels reserved for post-Soviet citizens, transport companies han-

23. Bulat Khusainov, "Kazakhstan: Economic Development under Globalization," Central Asia and the Caucasus, no. 4, 2001, p. 133.

24. "Kitajskaja i kazakhstanskaja kompanii sozdali SP po dobyche zolota v Kazakhstane" (Chinese and Kazakh companies have established a joint venture for extraction of gold in Kazakhstan), Ros/nvest, 7 September 2005, http://www.rosinvest.com/news/ 126039/, consulted 8 November 2005.

25. lida Ashimbaeva, "Dostizhenija i problemy kazakhstansko-kitajskikh ekonomicheskikh otnoshenij," op. cit.

26. Konstantin Syroezhkin, Problemy sovremennogo Kitaja i bezopasnost' v Central'noj Azii (Problems of contemporary China and security in Central Asia), Almaty, KISI, 2006, p. 272

27. Statement by Vladimir Paramonov, quoted in Murat Omarov, "Tovarooborot Kyrgyzstana s Kitaem" (Trade between Kyrgyzstan and China), Analytica, 4 June 2007, www.analitika.org/article.php?story=20070528232957997, consulted 19 August 2008.

28. Discussion with Dosym Satpaev, Almaty, 6 March 2008.

29. For further details on the different types of trade between China and Central Asia, see Gaël Raballand, Agnès Andrésy, "Why should Trade between Central Asia and China continue to expand?," op. cit., and Gaël Raballand, "La déferlante économique chinoise et ses conséquences en Asie centrale" (The Chinese economic tidal wave and its consequences in Central Asia), Monde chinois, no. 11, 2007, pp. 129-134.

30. Hu Hunpin, "Dal'nejshee usilenie ekonomicheskogo sotrudnichestva mezhdu SUAR KNR i Kazakhstanom v ramkakh SHOS" (The future strengthening of economic cooperation between Xinjiang and Kazakhstan under the umbrella of the SCO), in Problemy ekonomicheskogo i finansovogo sotrudnichestva $v$ ramkakh SHOS (Problems of economic and financial cooperation under the umbrella of the SCO), Almaty, KISI, 2006, pp. 146152

31. Vladimir Babak, "Astana v treugol'nike Moskva, Vashington, Pekin. Kazakhstansko-kitajskie otnoshenija" (Astana in the Moscow-Washington-Beijing triangle: ChinaKazakhstan relations), Centralnaja Azija i Kavkaz, no. 1, 2000, http://www.cac.org/journal/cac-07-2000/19.babak.shtml, consulted 25 August 2008

32. Konstantin Syroezhkin, Problemy sovremennogo Kitaja i bezopasnost' v Central'noj Azii, op. cit., p. 134. 
dling customs formalities, etc.) now reportedly consume some $\$ 4$ billion of goods per annum. ${ }^{(33)}$

The shuttle trade has been strongly criticised by Kazakh experts, who blame it for the poor quality of Chinese goods bought at the lowest possible prices by Central Asian traders. The Beijing authorities have also expressed concern at the deteriorating image of Chinese products in the region. In the summer of 1993, the Committee of Chinese Entrepreneurs issued an order making it a criminal offence to produce and distribute poor quality goods, while the Kazakh authorities agreed to exercise greater control over the activities of Kazakh and Chinese traders. In September 1995, during Nursultan Nazarbaev's official visit to Beijing, the two parties signed a document on quality control for imported and exported goods. ${ }^{(34)}$ In addition, fearing a Chinese "flood" of migrants onto its territory, Astana refused to lift visa regulations (which Kyrgyzstan did until 2003), even though it implemented simplified procedures enabling visas to be obtained at border posts.

Chinese companies are increasingly setting up in Kazakhstan. There were already 300 Chinese-Kazakh joint ventures in 1995. ${ }^{(35)}$ In 2007, according to figures from the Ministry of Justice, 78 subsidiaries of Chinese companies and approximately 4,000 Chinese-Kazakh joint ventures were accredited in the country. ${ }^{(36)}$ These joint ventures, focused on trade rather than production, concern local experts, who see them as confirming the suspicion that China is exploiting Kazakhstan's raw materials without enabling the country to obtain technological knowhow. ${ }^{(37)}$ Alida Ashimbaeva states that more than 600 Chinese-owned enterprises are active, mainly in the petroleum sector (extraction, processing, transportation, etc.). ${ }^{(38)}$ Konstantin Syroezhkin questions their real activities: the majority of Chinese-owned enterprises are categorised as wholesale trading companies, a vague term that can hide a wide range of potentially illegal activities. ${ }^{\left({ }^{39}\right)}$ In addition, almost two thirds of registered Chinese companies no longer provide information about themselves or quickly become inactive, which would seem to confirm the suspicion that some Chinese businessmen obtain a legal cover and then disappear into the underground economy. ${ }^{(40)}$

In addition, a large number of labour disputes in major Chinese petroleum companies, CNPC in particular, have attracted the attention of the Kazakh media in recent years. In Aktobe, Atyrau, and Kzyl-Orda, Chinese companies are criticised for primarily employing workers from China (who live within the company compound without any contact with the outside world), and consequently having little impact on high levels of unemployment in these regions. With the requirement to employ a minimum number of locals, Kazakhs who work in these enterprises are said to receive lower salaries than the Chinese and to be relegated to the most difficult jobs. ${ }^{(4)}$ In addition, Astana has reportedly permitted these enterprises to operate according to Chinese labour law rather than Kazakh labour law, thus inhibiting union activities by Kazakh employees, and outraging public opinion by requiring Kazakh employees to salute during the Chinese national anthem. ${ }^{(42)}$ Kazakh courts have issued penalties to Chinese companies for more than 300 contraventions of the labour code or environmental standards. ${ }^{(4)}$ In light of the proliferation of Chinese companies throughout the country, and not only in the border regions, some experts see a deliberate strategy of developing a network throughout the country so that in the event of serious political tensions, Beijing could interfere in Kazakhstan's internal development on the pretext of safeguarding its enterprises. ${ }^{(4)}$

\section{The most buoyant sectors of Chinese involvement}

China has brought Kazakhstan new technologies and modern financial and banking structures that are capable of providing a framework for the country's development and its entry on the world stage. The rapidly growing telecommunications sector is of particular interest to Chinese companies. While the major Russian telecommunications companies (MTS, BeeLine, Megafon) dominate the service market, China is

33. Vladimir Paramonov, Aleksej Strokov, "Ekonomicheskoe prisutstvie Rossii i Kitaja v Central'noj Azii," op. cit., p. 10.

34. Vladimir Babak, "Astana v treugol'nike Moskva, Vashington, Pekin. Kazakhstansko-kitajskie otnoshenija," op. cit.

35. Ibid.

36. Konstantin Syroezhkin, "Bol'shaja igra v central'no-aziatskom regione," Ekonomicheskie strategii - Central'naja Azija, no. 5, 2007, pp. 48-55

37. M. Namazbekov, "Torgovo-ekonomicheskoe sotrudnichestvo Kazakhstana s Kitaem kak faktor obespechenija bezopasnosti v Central'no-aziatskoj regione" (Trade and economic cooperation between Kazakhstan and China as a factor in the security of the Central Asian region), Analytic, no. 4, 2003, p. 21.

38. lida Ashimbaeva, "Dostizhenija i problemy kazakhstansko-kitajskikh ekonomicheskikh otnoshenij," op. cit.

39. Konstantin Syroezhkin, Problemy sovremennogo Kitaja i bezopasnost' v Central'noj Azii, op. cit., p. 182

40. Ibid.

41. Interview with Bektas Mukhamedzhanov, Almaty, 5 March 2008.

42. Interview with Murat Auezov, Almaty, 10 March 2008.

43. Gul'den Zholamanova, "0 nekotorykh aspektakh kazakhstansko-kitajskogo ekonomicheskogo sotrudnichestva v ramkakh SHOS: Politologicheskij analiz," op. cit., pp. 27-37.

44. Interview with Konstantin Syroezhkin, Almaty, 4 March 2008, and Murat Auezov, Almaty, 10 March 2008. 
establishing itself in the technology sector. As early as 1998, China Telecom developed its first joint telephone network with Kazakhstan. Negotiations in this area were undertaken under the umbrella of the SCO, which also guarantees its member countries the acquisition of technologies for control of the Internet. In 2001, the national company Kazakhtelecom agreed to use Chinese cables rather than expensive European cables in the Transit Asia Europe Fibre Cable System designed to unify telecommunication lines between Europe and Asia. ${ }^{(4)}$ In 2002, the Shenzhen Zhongxing Telecom Equipment Corporation (ZTE) signed a contract with Kazakhtelecom for development of the wireless telephone network and the installation of more efficient switching systems. In 2004, it invested more than $\$ 200$ million in the CDMA-450 network (Code Division Multiple Access) in Kazakhstan via a Chinese-Kazakh joint venture, Kazakhstan Engineering, 51 percent owned by Astana. China Telecom opened an office in Almaty in order to increase its presence in the country and provide the necessary services to Chinese companies that had already been established there. Finally, it is worth mentioning the banking sphere, which represents one of the most dynamic sectors of Kazakhstan's economy. Boosted by the petroleum boom and the search for quick profits, the Kazakh banks borrowed substantial sums from US banks involved in hedge funds. The Kazyna Fund for Sustainable Development, which governs the Development Bank and whose role is to assist the development of the national economy outside the petroleum sector, is seeking to collaborate more closely with Chinese banks. In 2006, Kazyna and the China Development Bank established a joint fund of $\$ 5$ billion to finance investments in infrastructure. The China Development Bank also granted a loan of \$200 million to the Kazakh authorities for Chinese companies to build the Moynak hydroelectric power station at a total cost of $\$ 310$ million. Located approximately $200 \mathrm{~km}$ from Almaty on the river Charyn, this power station, scheduled for completion in 2009, will have a capacity of $300 \mathrm{MW}$ that will partly remedy southern Kazakhstan's electricity deficit. In February 2008, the Kazakhstan Development Bank was granted a new $\$ 100$ million line of credit by the China Development Bank for a ten-year period ${ }^{(46)}$.

\section{xinjiang's proximity: Economic opportunity and development of border posts}

In the Soviet era, economic relations between Central Asia and Xinjiang were extremely limited: Central Asia imported livestock and raw materials from the Xinjiang, and exported industrial products and equipment. ${ }^{(47)} \mathrm{A}$ few border posts closed to individuals were opened, such as Khorgos, Bakhty and Maikapchagay, while the Ili and Irtysh rivers were used for commercial river transport. The construction of a railway linking Urumqi and Alma-Ata had begun during the period of Chinese-Soviet friendship, but was interrupted by the conflict between the two communist powers. ${ }^{(48)}$ In 1988, even before the visit of Mikhail Gorbachev to Beijing, the Soviet Union and the PRC signed an agreement permitting citizens of their border regions to cross the border without a visa. The Kazakh and Kyrgyz Soviet Socialist Republics were then twinned with Xinjiang, and the first cross-border movement of people and goods occurred, primarily among small traders of the Kazakh, Kyrgyz, Dungan, and Uyghur nationalities. ${ }^{(49)}$ In December 1991, a Chinese delegation led by the Minister of Trade and Foreign Economic Relations undertook the first official visit to the freshly independent Republics of Central Asia, a trip that foreshadowed China's grand return to the region.

\section{The predominance of Kazakhstan-Xinjiang trade}

More than two thirds of China-Kazakhstan trade consists of trade between Xinjiang and Kazakhstan. ${ }^{(5)}$ In the autumn of 1991, Chinese Prime Minister Li Peng opened an international trade fair in Urumqi with the objective of developing foreign economic relations between Xinjiang,

45. "Kazakhstan zakupaet deshevyj Internet v Kitae" (Kazakhstan buys cheap Internet from China), Netoscope, 8 January 2001, http://www.netoscope.ru/news/2001/08/01/ 3052.html, consulted 9 November 2005.

Dosym Satpaev, "Kitaj na provode. K kazhdoj strane CentrAzii u Pekina svoj podkhod" (China on the march. Beijing has a specific approach for each of the countries of Central Asia), CentrAsia, 22 January 2007, www.centrasia.ru/newsA.php4?st=1169450220, consulted 11 April 2007.

46. "Bank razvitija Kazakhstan i Gosudarstvennyj bank razvitija Kitaja podpisali kreditnoe soglashenie na 100 millionov dollarov," Spy.kz, 21 February 2008, http://www.spy.kz/Econom/Bank-razvitija-Kazahstana-i-Gosudarstvennyi-bank-razvitija-Kitaja-podpisali-kreditnoe-soglashenie-na-100-millionov-dollarov/, consulted 17 August 2008.

47. For a history of relations between China and Central Asia up to 2002, see Thierry Kellner, L'Occident de la Chine, Pékin et la nouvelle Asie centrale (1991-2001), op. cit.

48. Viktor Krivonogov, "Kazakhstansko-kitajskie torgovo-ekonomicheskie i nauchnyetekhnicheskie otnoshenija" (Trade, economic, scientific and technological relations between Kazakhstan and China), Kazakhstan i sovremennyj mir, no. 1, 2003, pp. 24-41.

49. Elena Sadovskaja, "Kitajskaja migracija v Kazakhstane: sovremennye tendencii i perspektivy" (Chinese migration to Kazakhstan: current trends and perspectives), Analytic, no. 6, 2007, pp. 33-44.

50. Tchou Sjaopei, "Sotrudnichestvo mezhdu SUAR (KNR) i Kazakhstanom: dostizhenija i perspektivy" (Cooperation between Xinjiang and Kazakhstan: Outcomes and perspectives), Kazakhstan i sovremennyj mir, no. 3, 2004, pp. 206-209. 
Kazakhstan, and Kyrgyzstan. Over several months, four cities in Xinjiang, including Urumqi, offered a preferential tax scheme to foreign investors and businessmen. Trade between the two regions grew exponentially from 2002, with growth of 60 to 80 percent per annum. ${ }^{(5)}$ Thus, while the volume of Kazakhstan-Xinjiang cross-border trade reached a little more than $\$ 1$ billion between 1990 and 1993, it exceeded $\$ 10$ billion between 2000 and 2004. ${ }^{(52)}$ In 2007, trade was reported to be almost $\$ 12$ billion. ${ }^{(53)}$ It is increasing particularly in the northern border region of Xinjiang, which accounts for only 23 percent of the territory and half the population, but 70 percent of regional production due to its considerable resources, including the Karamay deposits, the Koktagay mines, and fertile agricultural areas. ${ }^{(54)}$

Economic relations between Kazakhstan and Xinjiang have evolved during the course of the decade. The export of standard consumer goods is no longer the main trade focus, and is now complemented by hydrocarbons. Kazakh companies have invested in Xinjiang in the transport, metals production, paper, and food production sectors - for example the company Raiymbek, a specialist in dairy produce and fruit juices. Kazakhstan has thus become the main foreign investor in Xinjiang, while Chinese investors from Xinjiang, for their part, are concentrated in the Almaty region. One of the main Xinjiang companies in Kazakhstan is Tsinkaz, which opened a tomato juice factory in Almaty. Chinese and Kazakh experts nevertheless state that bilateral cooperation between the two regions has not achieved its full trade potential, ${ }^{(55)}$ and that there is no genuine economic integration. ${ }^{(56)}$ Conscious of the potential, the Chinese authorities are seeking to strengthen relations by organising increasingly regular meetings at the highest levels. So it was that in September 2006, a delegation from Xinjiang met with the Kazakh parliament.

This geographic proximity makes it possible to strengthen China-Kazakhstan linkages in the area of inland transport. For example, the Eurasian Continental Bridge project, linking the port of Lianyungang on the Pacific coast to Western Europe via Lanzhou, Urumqi, Dostyk, and Russia over more than 10,000 km, including 3,200 km in Kazakhstan, has necessitated the upgrading of some sections of road. ${ }^{(57)}$ For instance China is upgrading the section from Khorgos to Chymkent via Almaty. ${ }^{\left({ }^{88}\right)}$ Several highways linking the main cities of Xinjiang to those in Kazakhstan have been opened (a matter of unifying and rehabilitating already existing sections): in March 2008, the two countries announced the opening of seven new highways between Urumqi and Karaganda, four for the transport of goods and three for pas- senger traffic, via the border posts of Khorgos, Zheminay, and Alashankou. Kazakhstan-Xinjiang cooperation is also rail-based: despite pressures from Moscow, which wants to hold on to its market, the Kazakh national railway company, Kazakhstan Temir Zholy, agreed in 2006 to purchase passenger carriages from the Chinese Tian Shan factory at a cost of $\$ 60$ million. It is considering the possibility of purchasing additional stock from the China Railway New Express Transportation Equipment $\mathrm{Co}_{0}$, as well as rolling stock for the transport of agricultural produce. ${ }^{(59)}$

As with China-Kazakhstan relations as a whole, relations between Kazakhstan and Xinjiang do not have the unanimous approval of Kazakh researchers and a section of the political class. Indeed, Xinjiang's economy remains dominated by state production in raw materials and is only beginning to benefit from the technological dynamism of China's maritime regions. Too great a concentration of Kazakh trade with Xinjiang would therefore accentuate Astana's specialisation in raw materials and would prevent the development of trade relations with the eastern regions of China, particularly with the country's dozens of special economic zones. ${ }^{(60)}$ Alida Ashimbaeva believes that Beijing is openly seeking to limit Kazakhstan to the supply of raw materials to Xinjiang in order to accelerate Xinjiang's development at the expense

51. Irina Galkina, "Kitajskij sled v istorii" (China's footprint in history), Ekspert Kazakhstan, 4 July 2005.

52. Trade between Kazakhstan and Xinjiang was $\$ 903$ million in 2001, $\$ 1.365$ billion in 2002, $\$ 2.546$ billion in 2003, and $\$ 3.286$ billion in 2004. Konstantin Syroezhkin, Problemy sovremennogo Kitaja i bezopasnost' v Central'noj Azii, op. cit., p. 129.

53. "Sdacha $v$ ekspluataciju kitajsko-kazakhstanskogo mezhdunarodnogo centra prigranichnogo sotrudnichestva" (The opening of the China-Kazakhstan international centre for border cooperation), http://www.china-hongkong-business.ru/index. php?option=com_content\&task=view\&id=4142\&ltemid=2, consulted 5 August 2008.

54. Sh. Nadyrov, "Sin'czjan-ujgurskij avtonomnyj rajon v dinamike ekonomicheskikh i politicheskikh otnoshenij RK i KNR" (The autonomous Uyghur region of Xinjiang in the dynamic of economic and political relations between Kazakhstan and the PRC), Kazakhstan-Spektr, no. 1, 2006, pp. 14-25.

55. Hu Hunpin, "Dal'nejshee usilenie ekonomicheskogo sotrudnichestva mezhdu SUAR KNR i Kazakhstanom v ramkakh SHOS," op. cit.

56. Evgenij Savkovich, "Proekty ekonomicheskoj integracii Kitaja i Kazakhstana" (China and Kazakhstan's economic integration projects), Analytica, 4 September 2006, http://www.analitika.org/article.php?story=20060904033625413, consulted 26 August 2008.

57. Gul'den Zholamanova, "0 nekotorykh aspektakh kazakhstansko-kitajskogo ekonomicheskogo sotrudnichestva v ramkakh SHOS: politologicheskij analiz," op. cit., pp. 27-37.

58. "Po itogam 2007 goda Kitaj zanimaet 40e mesto v spiske torgovykh partnerov Kazakhstana," op. cit.

59. 'Kazakhstan rassmatrivaet vozmozhnost' priobretenija 38 passazhirskikh vagonov u kitajskoj kompanii" (Kazakhstan is considering the possibility of buying 38 passenge carriages from a Chinese company), Kazakhstan Today, 14 January 2006, http://www.gazeta.kz/art.asp?aid=69950, consulted 8 November 2006.

60. Irina Galkina, "Kitajskij sled v istorii," op. cit. 
of Kazakhstan's economy. ${ }^{(6)}$ According to Konstantin Syroezhkin, the "red, black, and white" specialisation of Xinjiang, that is, in fruit and vegetables, hydrocarbons, and cotton, will cause a number of ecological problems in the long term for Kazakhstan (management of drinking water, deterioration of soil quality), not to mention the competition between Xinjiang and Kazakhstan in these areas. ${ }^{\left({ }^{(2)}\right.}$

\section{The dynamism of the Chinese-Kazakh border posts}

The border posts and the free zones that are nearby or in the process of being established have rapidly become one of the driving forces behind the dynamism of ChinaKazakhstan trade. In 1993, Xinjiang's Science and Technology Committee proposed the creation of free trade zones in Inin-Zharkent, Dostyk-Alatau, and Boro-Tala in the autonomous Mongol border region of Xinjiang. In 1996, Beijing proposed the creation of a free zone for four players in the Altay region, where China, Russia, Kazakhstan, and Mongolia to all intents and purposes share a common border (the latter two are only about $50 \mathrm{~km}$ away), but this was unsuccessful. A decade later, the growing role of the free zones motivated the government of Xinjiang to propose the creation of a China-Kazakhstan management body for the special economic zones and better utilisation of common border territory. ${ }^{(63)}$ In 2007, China proposed a triangle of growth in the Urumgi-Aktagay-Almaty zone that would enable Russia to take advantage of China-Kazakhstan trade and develop its part of the Altay. ${ }^{(64)}$

The first border post to open was Dostyk-Alatau (Alashankou) in 1992. Located in the Almaty region, near Zharkent, it rapidly became the main Chinese-Kazakh transshipping post, now handling 50 percent of all trade between Kazakhstan and Xinjiang, and 90 percent of the border trade. The governments of both countries would like to see Dostyk-Alatau become a true international transport hub; indeed, apart from the China-Kazakhstan pipeline (cf. infra), it has a strategic rail link - for the moment, the sole railway line linking China and Central Asia (AlmatyUrumqi). The amount of container freight being moved through Dostyk-Alatau has increased rapidly, from 7 million tonnes in 2004 to 11 million tonnes in 2005 and 13 million tonnes in 2006. ${ }^{(5)}$ Out of the 15 million tonnes that were freighted through this post in 2007, 11.5 million were shipped from Kazakhstan to China (primarily ferrous metals, non-ferrous metals, and petroleum), and only 3.5 million tonnes from China to Kazakhstan. ${ }^{(6)}$ The Kazakh authori- ties hope that the volume of freight handled by the rail terminal at Dostyk will reach 20 million tonnes by 2010 . Despite its dynamism, the border post still experiences difficulties in keeping up with the explosion of ChinaKazakhstan trade. Customs formalities delay the flow of goods by several days, and passengers have to wait for hours while the wheels are changed because of the different rail gauge between the post-Soviet territories and China. ${ }^{(6)}$ The market town of Dostyk, however, is increasingly becoming a small business hub. A free trade zone has been mooted by Astana in order to stimulate development in the region, based on the successful model of Khorgos.

While Dostyk-Alatau dominates through its rail transport, the second border post of Khorgos has become the main China-Kazakhstan road transport hub. Opened in 2004, it is located further to the south, on the small river of Khorgos, only $90 \mathrm{~km}$ from Kuldzha and $370 \mathrm{~km}$ from Almaty. In 2003, the Kazakh and Chinese authorities announced the creation of a free zone to encourage trade, making Khorgos Xinjiang's first free zone and China's first cross-border zone. ${ }^{(68)}$ In 2006, the goods trade amounted to more than $\$ 1$ billion, representing an increase of 35 percent compared to the previous year. ${ }^{(69)}$ In 2007 , more than 3 million people and 2 million tonnes of goods reportedly passed through the

61. Alida Ashimbaeva, "Starye problemy novoj ekonomiki Kazakhstana" (Old problems of the new economy of Kazakhstan), Kapital.kz, no. 21 (108), 31 May 2007, republished in CentrAsia, 2 June 2007, www.centrasia.ru/newsA.php?st=1180737420, consulted 15 July 2008.

62. Konstantin Syroezhkin, "Strategija 'bol'shogo osvoenija zapada' i problemy bezopasnosti Central'noj Azii" (The strategy of development of the 'Great West' and problems of security in Central Asia), Analytic, no. 2, 2007, pp. 22-32.

63. Oleg Sidorov, "Kitajskij faktor na evrazijskom kontinente" (The Chinese factor on the Eurasian continent), Gazeta.kz, http://www.gazeta.kz/art.asp?aid=798411, consulted 15 August 2008.

64. lida Ashimbaeva, "Dostizhenija i problemy kazakhstansko-kitajskikh ekonomicheskikh otnoshenij," op. cit.

65. Embassy of Kazakhstan in China,http://www.kazembchina.org/create/bike/ home.jsp?tablename=itemcontent\&iiid=7386256821857348225\&tableFlag=itemtable, consulted 15 August 2008.

66. lida Ashimbaeva, "Dostizhenija i problemy kazakhstansko-kitajskikh ekonomicheskikh otnoshenij," op. cit.

67. Nicklas Swanström, Nicklas Norling, Zhang Li, "China," in Frederick Starr (ed.), The New Silk Roads. Transport and Trade in Greater Central Asia, Washington D.C., The Central Asia and Caucasus Institute, 2007, p. 406.

68. For further detail, see Sébastien Peyrouse, "The Economic Aspects of the ChineseCentral-Asia Rapprochement," Silk Road Papers, Washington DC, The Central Asia and Caucasus Institute, 2007, 74 pp.http://www.silkroadstudies.org/new/docs/ Silkroadpapers/2007/0709ChinaCentral_Asia.pdf.

69. "Voprosy razvitija centra Khorgos i zheleznodorozhnogo perekhoda Dostyk-Alashan'kou obsuzhdeny v pravitel'stve RK" (The Kazakhstan government is considering issues of development of the centre of Khorgos and the Dostyk-Alashan'kou rail connection), KazInform, 4 May 2007, http://www.nomad.su/?a=3-200705070234, consulted 17 June 2007. 


\section{Special feature}

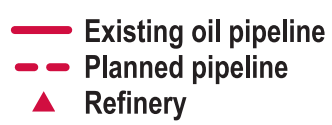

Phase 1: Atyrau - Kenkiyak

Phase 2: Atasu - Alashankou / Druzhba

Phase 3: Kenkiyak - Kumkol'

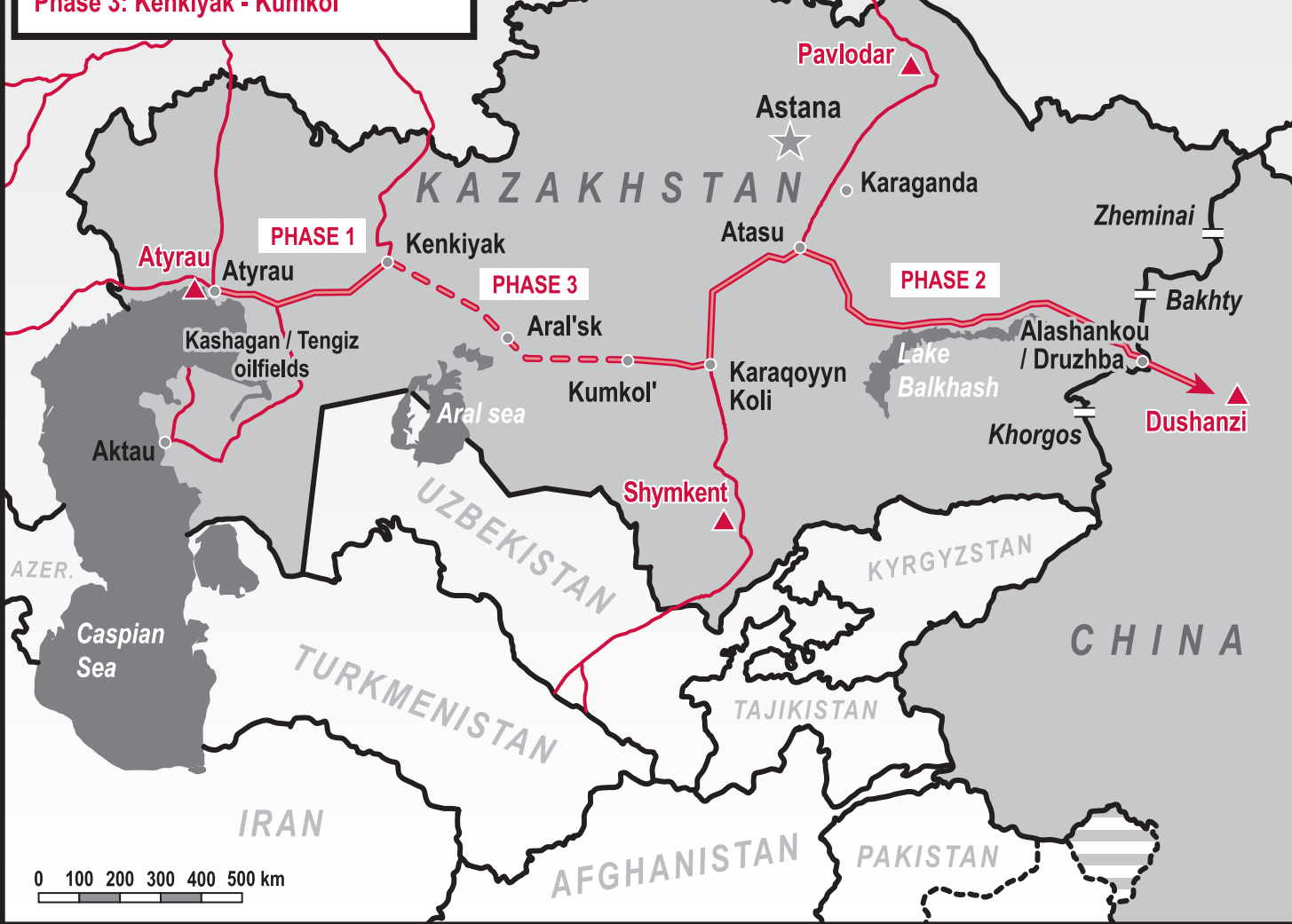

zone. ${ }^{(70)}$ Once the Shihezi-Yining-Khorgos road is upgraded, the trip from Urumqi to Almaty will be reduced by $200 \mathrm{~km}$, increasing its profitability. In response to the dynamism of Khorgos, transport infrastructure is growing: a new railway line linking Urumqi and Almaty via Khorgos is due to become operational in 2009 and will double the capacity of Dostyk's rail line, which will soon be overstretched. ${ }^{\left({ }^{(7)}\right)}$ It will be accompanied by the construction of a dry port that will house a logistical redistribution centre, significant storage capacity, and communication services.

In April 2008, the Kazakh government announced the construction at Khorgos of an airport capable of landing Boeing747 s, at an estimated cost of some $\$ 500$ million. ${ }^{(72)}$ Since 2005 , construction of a hydroelectric power plant has also been foreshadowed by a series of small power stations located about $20 \mathrm{~km}$ from the border post on the Khorgos River, a tributary of the Irtysh. Production of electricity will be shared equally by the two countries, and regulation of the river's flow will enable agricultural areas along both sides of the border to be extended. ${ }^{(73)}$ Khorgos has not only become the main road transport point, it is also a highly successful free zone, a model for those envisaged in the rest of Kazakhstan and in other border states such as Kyrgyzstan and Tajikistan. The free zone of Khorgos, opened in 2006, has become the principal one in Xinjiang: more than 200 enterprises specialising in new technologies and manufactured products have been established on the Chinese side. In the area controlled jointly by the two countries, an International Centre for China-Kazakhstan Cross-Border Cooperation is due to begin operation at the end of 2008 .

70. "Sdacha v ekspluataciju kitajsko-kazakhstanskogo mezhdunarodnogo centra prigranichnogo sotrudnichestva," op. cit

71. "Po itogam 2007 goda Kitaj zanimaet $40 \mathrm{e}$ mesto v spiske torgovykh partnerov Kazakhstana," op. cit.

72. "V kazakhstanskom poselke Korgas na granice s Kitaem postrojat aeroport" (An airport will be built in the Kazakh village of Khorgos on the border with China), http://www.tio.kz/news/V-kazahstanskom-poselke-Korgas-na-granice-s-Kitaempostrojat-aeh.html, consulted 2 September 2008.

73. For further detail on China-Central Asia cooperation in hydroelectricity sector, cf Sébastien Peyrouse, "The Hydroelectric Sector in Central Asia and the Growing Role of China," China and Eurasia Forum Quarterly, vol. 5, no. 2, 2007, pp. 131-148, http://www.silkroadstudies.org/new/docs/CEF/Quarterly/May_2007/Peyrouse.pdf. 
Covering an area of more than 15 square kilometres, it will house hotels, parks and, in particular, showrooms for Chinese products and new technologies, which will be offered duty free, together with all the logistical services required for the shipping of goods. ${ }^{(74)}$

There are three other Chinese-Kazakh border posts, but at present these remain dedicated to border trade. The post of Kolzhat-Dulart, 340 km from Almaty, is located between Narynkol and Khorgos. It seems destined for rapid development, as the Aksay-Chundzha-Kolzhat road section, which crosses the Uyghur autonomous district, is in the process of being upgraded. ${ }^{(75)}$ On the Chinese side, Durlat has been considered an international port since 1994. Although a free trade zone was opened in 1999, movement remains restricted: in 2002, 6,000 people, 3,000 vehicles, and 24,000 tonnes of goods passed through it. ${ }^{(76)}$ The two other posts, Bakhty-Tacheng and Maikapchagay-Zheminay, located further to the north in the region of eastern Kazakhstan, near Lake Zaysan, are capable of servicing all of north-eastern Kazakhstan, and even the Russian Altay. The Kazakh authorities are funding the upgrading of the TaskenskenBakhty road in order to increase the post's capacity to transport goods, while on the Chinese side, the market town of Tacheng now has a small airport open to commercial flights. The post of Maikapchagay-Zheminay is also undergoing considerable development: in March 2006 the Chinese authorities created a free zone, the second after Khorgos, able to house up to 10,000 stands and 3,000 tonnes of freighted goods. ${ }^{(77)} \mathrm{A}$ visa-free scheme enables border dwellers to visit the trade zone. ${ }^{(78)} \mathrm{A}$ sixth post, Narynkol-Muzart, located near the Kyrgyz border, which opened in 1992, has closed due to lack of traffic. A seventh crossing point, Alekseevka, located more than $800 \mathrm{~km}$ from Urumqi and close to Russia, could come into operation in the years ahead.

\section{The energy sector, a driving force behind China's presence in Kazakhstan}

Having recently become one of the greatest consumers of hydrocarbons in the world, China has difficulty quenching its thirst for energy: it is expected to consume 400 million tonnes of petroleum in 2020, 60 percent of which will need to be imported. ${ }^{(79)}$ In order to diversify their supply from the Middle East and its geopolitical vicissitudes, the Chinese authorities have turned to Kazakhstan, which according to British Petroleum is now in eighth position for proven reserves of petroleum, but in only 18th position for the vol- ume of petroleum extracted. ${ }^{(80)}$ By 2020, Astana hopes to become one of the ten largest exporters of crude oil. China's energy needs are destined to grow to such an extent that Beijing is trying to diversify its sources by turning to nuclear energy and also to coal-fired electricity. Once again, Kazakhstan's proximity appears a godsend, and new directions in China-Kazakhstan economic relations are beginning to take shape around these areas.

\section{Petroleum and natural gas fields operated by Chinese companies}

Prime Minister Li Peng began negotiations with the Kazakh authorities in 1994, but it was not until 1997 that the China National Petroleum Corporation (CNPC) and its subsidiaries actually commenced operation in Kazakhstan, as a result of a bilateral agreement on cooperation in the hydrocarbons sector that provided for acquisitions of oil and gas fields and the construction of a pipeline. China finally confirmed its status as a major partner in the Kazakh energy market in 2003 with the commissioning of the AtasuAlashakou pipeline, the acquisition of new oil and gas fields, and the arrival on the Kazakh scene of Chinese companies other than CNPC.

Despite its efforts, Beijing has not succeeded in establishing a foothold in the two main Kazakh oil and gas areas, the onshore site of Tengiz, and the offshore site of Kashagan. Indeed, Astana, like the western investors in the North Caspian Sea Project consortium, has refused to entertain China's involvement in the geopolitically-sensitive Caspian deposits. Despite this, Kazakhstan seemed to retract this Caspian veto partially in 2005, when the China National Offshore Oil Corporation (CNOOC) and KazMunayGaz signed an agreement for exploration of the Darkhan offshore deposit located between

74. lida Ashimbaeva, "Dostizhenija i problemy kazakhstansko-kitajskikh ekonomicheskikh otnoshenij," op. cit.

75. "Stroitel'stvo i rekonstrukcija avtodorogi Aksaj-Chundzha-Kolzhat nachalis' v Almatinskoj oblasti" (The construction and upgrading of the Aksay-Chundzha-Kolzhat freeway has begun in the region of Almaty), Professional, no. 121, 24 April 2006 , http://www.professional.kz/?mod=text\&tx=067075, consulted 19 August 2008.

76. See the web site devoted to the borders and dry ports of Xinjiang: http://www.china org.cn/english/features/Xinjiang/114781.htm, consulted 23 August 2008.

77. "China boosts trade ties with Kazakhstan," Washington Profile, 2 February 2006 http://www.washprofile.org/en/node/4593, consulted 15 June 2007.

78. lida Ashimbaeva, "Dostizhenija i problemy kazakhstansko-kitajskikh ekonomicheskikh otnoshenij," op. cit.

79. P. Sergeeva, "Atasu-Alashan'kou: vchera, segodnja, zavtra" (Atasu-Alanshan'kou: yesterday, today, tomorrow), Analytica, 17 January 2007, http://www.analitika.org/ article.php?story=20070117023100978, consulted 23 August 2008

80. "Kazakhstan," Country Brief Analysis, Energy Information Administration http://www.eia.doe.gov/emeu/cabs/Kazakhstan/pdf, consulted 23 August 2008. 
the Kurmangazy and Karazhambas fields, the reserves of which are estimated to be 11 billion barrels of petroleum. Negotiations for its exploitation are in progress. The acquisition of this site has enabled China to gain a foothold, albeit a modest one, in the Caspian Sea. In addition to Darkhan, its only offshore site, CNPC now operates six onshore sites. China's long-term strategy is to secure supply to the pipeline by acquiring secondary deposits along its route, enabling it to avoid pressures from foreign companies to supply the oil pipeline.

CNPC's main acquisition remains the AktobeMunayGaz company, in which it purchased a 60 percent share in 1997 and a further 25 percent in 2003. ${ }^{(81)}$ Located in the Aktobe region, it controls almost 15 percent of Kazakh petroleum, and in particular holds a 20-year licence for exploitation of the Zhanazhol and Kenkiyak petroleum and gas sites, which represent 5 percent of Kazakhstan's total petroleum reserves. ${ }^{\left({ }^{(2)}\right)}$ Its acquisition has clearly been profitable, production having doubled between 1997 and 2006, when the Chinese company produced 10 million tonnes of petroleum and 1.5 billion cubic metres of gas. ${ }^{(83)}$ In 2008, CNPCAktobeMunayGaz produced 120,000 barrels per day, not quite the 200,000 they were hoping for by the end of the decade. ${ }^{\left({ }^{(8)}\right)}$ China declared that it had invested $\$ 1.5$ billion in the site, primarily for renovation of the refinery and construction of the Zhanazhol gas conversion plant, as well as for storage and processing. ${ }^{(85)}$ The UzenMunayGaz site, located on the Mangistau peninsula, also acquired in 1997, has been less successful, with CNPC withdrawing in 2005. According to Astana, the Chinese company did not meet its investment obligations and therefore lost the right to manage the site, ${ }^{(86)}$ whereas Beijing claims that the site was handed back to KazMunayGaz when exploitation proved unprofitable. ${ }^{(87)}$

After this dual purchase in 1997, six years passed before China invested further in the Kazakh market with the 2003 acquisition of a 35 percent stake in the Buzachi North company at Nimir Petroleum, followed by acquisition of the remaining 65 percent share from Texaco. However, in December 2003, CNPC suddenly decided to transfer half of its share to the CanadianKazakh company Nelson Resources Ltd., which was then bought out by Lukoil. ${ }^{(8)} \mathrm{CNPC}$ and Lukoil have been in dispute ever since over the right of pre-emption over half the site, but they continue to exploit it. Located north of Aktau in the Mangistau region, it has reserves estimated at 205 million tonnes. ${ }^{\left({ }^{(8)}\right)}$ In 2008, its daily production was 33,000 barrels of petroleum and 127,000 cubic metres of natural gas. ${ }^{(90)}$ More than half the petroleum extracted there is sold to the West through the Atyrau-Samara pipeline. The dispute with Lukoil also casts doubt on CNPC's exploitation rights to the Bars deposit near the Buzachi deposit, the oil reserves of which, covering 5,600 square kilometres, would appear to be particularly promising (more than 200 million tonnes).

In 2005, CNPC attracted attention through its acquisition, at a cost of almost $\$ 4.3$ billion, of the Canadian company PetroKazakhstan. With almost 12 percent of Kazakh production, including the major site of Kumkol, PetroKazakhstan is considered the second largest foreign petroleum producer based in Kazakhstan and the main producer and supplier of refined products in the country. This represented the most important acquisition ever undertaken by the Chinese company on foreign soil, and made Kazakhstan CNPC's second production base outside China, after Sudan. In 2006, Astana demanded that CNPC sell one third of the company to KazMunayGaz, which China agreed to do. The main area of activity of PetroKazakhstan, which fully or partially owns 11 sites as well as exploration rights to five blocks, is located in the Turgay basin in the Kzyl-Orda and South Kazakhstan regions, as well as the Aktobe region. ${ }^{(91)}$ The company is also joint owner, with KazMunayGaz, of the Shymkent refinery, the largest in the country, and handles the sale of refined products in Kazakhstan. However, this acquisition triggered a still-unresolved legal dispute with Lukoil and its subsidiary Turgay Petroleum. ${ }^{(92)}$

81. Irina Galkina, "Kitajskij sled v istorii," op. cit.

82. "Prisutstvie Kitaja v Kazakhstane: 'Dostizhenija' i 'perspektivy'” (China's presence in Kazakhstan: 'success' and 'perspectives'), Zona.kz,http://zonakz.net/articles/ ?artid=13774, consulted 17 August 2008.

83. Dun Sjaojan, "Nekotorye voprosy kitajskogo-kazakhstanskogo energeticheskogo sotrudnichestva" (Questions about China-Kazakhstan energy cooperation), Kazakhstan $\checkmark$ global'nykh processakh, no. 3, 2005, pp. 32-40.

84. "Kazakhstan-CNPC/AktyubinskMunaiGaz," APS Review Gas Market Trends, 28 July 2008, http://www.entrepreneur.com/tradejournals/article/181878714.html, consulted 2 September 2008

85. See the official site of the CNPC, http://www.cnpc.com, consulted 28 August 2008.

86. Bakhytzhan Zhumalieva, "Kazakhstan i Kitaj: vzaimovlijanie i sotrudnichestvo" (Kazakhstan and China: mutual influence and cooperation), Ekonomicheskie strategii Central'naja Azija, no. 5, 2007, pp. 42-47.

87. Andrei Chebotarev, "Kazakhstan: Priority Oil Routes," Central Asia and the Caucasus, vol. 9, no. 3, 2001, pp. 29-30.

88. Bulat Khusainov, "Severobuzachinskaja intriga" (The North Buzachi intrigue), Ekspert Kazakhstan, no. 1, 19 January 2004, http://www.expert.ru/printissues/kazakhstan/2004/01/01ka-knelson/, consulted 17 February 2007.

89. For further detail, see Sébastien Peyrouse, "The Economic Aspects of the ChineseCentral Asia Rapprochement," op. cit., pp. 52-53.

90. "Kazakhstan Major Oil and Natural Gas Projects," Energy Information Administration, http://www.eia.doe.gov/emeu/cabs/kazaproj.html, consulted 31 August 2008.

91. "CNPC in Kazakhstan," http://www.cnpc.com.cn/eng/cnpcworldwide/euroasia/ Kazakhstan/, consulted 26 August 2008.

92. Kalamkas Esimova, "Kazakhstansko-kitajskoe energeticheskoe sotrudnichestvo v 2005 g.," Analytic, no. 4, 2006, p. 41-43. 
Apart from these three main sites, which form the core of China's petroleum presence in Kazakhstan, CNPC has subsidiaries established in several small sites in the exploration or exploitation phases, all located close to the China-Kazakhstan pipeline. In 2004, CNPC and China North Industries Corporation acquired a 50 percent share in the Konys and Bektas sites (KAM project) in the Turgay basin, which reportedly contain reserves of 21 million tonnes of petroleum. ${ }^{(93)} \mathrm{In}$ the same year, Sinopec acquired the American First International Oil Company (FIOC), which holds exploitation licences for small deposits located in the west of the country, in particular the promising site of Aday, the petroleum reserves of which are estimated at 100 million tonnes, along with gas reserves estimated at 400 billion cubic metres, which it manages with Rosneft. In 2005, CNPC acquired a 100 percent interest in ADM, which exploits the two Aryss and Blinov blocks, with reserves estimated at 10 million tonnes of petroleum. ${ }^{(94)}$ In the same year, the China National Oil and Gas Exploration and Development Corporation (CNODC) become the sole shareholder in the petroleum company Aydan Munay, which gives it control over virtually all the sites in the Kzyl-Orda region. ${ }^{(95)}$ Finally, the site of Satpaev, the reserves of which are estimated at 1.85 billion barrels of petroleum, is the subject of negotiations between the Oil and Natural Gas Corporation (ONGC) and KazMunayGaz.

In December 2006, the Chinese investment company CITIC Group (China International Trust and Investment Company), based in Hong Kong, acquired the Nations Energy company, which holds the exploitation rights to the Karazhanbas site in the Mangistau region, the certified reserves of which are more than 340 million barrels of petroleum. In November 2007, the CITIC Group sold half its interest in Karazhanbas to KazMunayGaz. In less than a decade China has thus become an important player in Kazakhstan's energy market. However, its presence is represented by conflicting figures: according to some sources, Chinese companies controlled only 16 percent of annual extraction in 2006, or a little more than 10 million tonnes of petroleum. ${ }^{(96)}$ This seems to be an underestimate, since the majority of experts state that Chinese companies produced almost 18 million tonnes of crude petroleum during that year, representing 26 percent of Kazakhstan's total production. ${ }^{(97)}$

\section{The China-Kazakhstan oil pipeline and the China-Central Asia gas pipeline}

In addition to acquiring oil and gas fields, China is investing in the pipelines that enable it to secure its supplies, even though production at some sites acquired by Beijing in the west of Kazakhstan is exported to Europe via the Russian pipelines and the Caspian Pipeline Consortium (CPC). China's current strategy remains one of linking the different deposits it has acquired to the pipeline that is under construction. A proposed oil pipeline connecting Kazakhstan and China had been considered as early as 1997 but only became a reality in 2003. The difficult Russian-Chinese negotiations over the Angarsk-Daqing oil pipeline lent weight to the Kazakh alternative, as did the rise in the price of raw materials and the discovery of the Kashagan deposit. The first section, the Northwest Crude Pipeline, brought into operation in 2003, links the Kenkiyak field to the main city in the west of the country, Atyrau, the petroleum capital of Kazakhstan, thus enabling Chinese petroleum to flow to the Russian pipelines and on to Western Europe. CNPC owns a 49 percent share in this oil pipeline, the first constructed following Kazakhstan's independence. At 448 km in length, its capacity is expected to reach 14 million tonnes per annum. A second section, the Kazakhstan-China Crude Oil Pipeline in the east of the country, stretches from the station of Atasu, in the Karaganda region, to the ChineseKazakh border post of Dostyk-Alatau. At $962 \mathrm{~km}$ in length and with a cost of $\$ 800$ million funded by CNODC and KazMunayGaz, it is the first oil pipeline to link Kazakhstan to a foreign market without passing through a third country. Its capacity is expected to double to 20 million tonnes per annum through an exclusively Chinese funding arrangement. ${ }^{(98)}$ Finally, a third section in central Kazakhstan, construction of which began in December 2007, links Kenkiyak to Kumkol via the town of Aralsk over a distance of $760 \mathrm{~km}$ and at an estimated cost of \$511 million. In 2010-2011, when this last section is due to be completed, China will be able to make a decision on reversion of the Kenkiyak-Atyrau section, heading eastwards, and will link Kumkol to Atasu by an already existing pipeline constructed during the Soviet period. It will thus have the advantage of an oil pipeline

93. http://www.cnpc.com.cn/eng/cnpcworldwide/euro-asia/Kazakhstan/.

94. Ibid.

95. "Prisutstvie Kitaja v Kazakhstane: 'Dostizhenija' i 'perspektivy'," op. cit.

96. Aleksandr Ivanter, "Kazakhstan: Barkhatnaja nacionalizacija" (Kazakhstan: A velvet nationalisation), Ekspert, no. 46, 2007, http://www.expert.ru/printissues/kazakhstan/2007/46/neftyanaya_promyshlennost/, consulted 17 August 2008.

97. Yitzhak Shichor, "China's Central Asian Strategy and the Xinjiang Connection: Predicaments and Medicaments in a Contemporary Perspective," China and Eurasia Forum Quarterly, vol. 6, no. 2, 2008, p. 69.

98. "The 'Great Game' goes on," Petroleum Review, 26 February 2007, http://www.uofaweb.ualberta.ca/chinainstitute/nav03.cfm?nav03 $=57276 \&$ nav02 $=572$ 75\&nav01=57272, consulted 12 August 2008. 
Sino-kazakh pipeline segment between Atasu and Alashankou (Kazakhstan).

(C) AFP

more than $3,000 \mathrm{~km}$ in length $(2,818 \mathrm{~km}$ in Kazakh territory and $270 \mathrm{~km}$ in Chinese territory) and with a capacity of 20 million tonnes, linking the Caspian Sea to Xinjiang. Xinjiang will in turn be linked to the internal Chinese network, elements of which either already exist or are under construction, and which supplies the major cities on the Pacific coast that are China's major energy consumers. ${ }^{(99)}$

However, the question of supply to the China-Kazakhstan pipeline remains problematic, all the more so since constant delays in oil and gas field development in Kashagan, now on hold until 2013, and difficulties in moving to intensive development at Tengiz, are curbing the ambitions of both Kazakhstan and China. In 2007, Kazakhstan exported only about 85,000 barrels per day to China, or 4.25 million tonnes, representing approximately 7 percent of Kazakhstan's total petroleum exports and 2.8 percent of China's. ${ }^{(100)}$ In the winter of 2007, Astana was even forced to temporarily close the Atasu-Alatau pipeline, which was operating at only 40 percent capacity due to lack of crude oil, while Beijing still had not completed renovation of the Dushanzi refinery in Xinjiang. ${ }^{(10)}$ Since 2006, negotiations with the Russian petroleum companies have been undertaken to encourage them to export part of their production to China via the Kazakh sections of pipeline. The Kazakh authorities hope, however, that once Kashagan is operational, they can become an independent player, supplying China with the anticipated 20 million tonnes per annum, while Beijing, for its part, hopes to have acquired sufficient sites to be able to manage supply to the oil pipeline independently. ${ }^{(102)}$ Lastly, the pipeline should secure 5 percent of the total volume of Chinese imports, a figure that could double ( 40 million tonnes out of the 400 required) after work is completed to increase the flows.

Since 2005-2006, a new large-scale energy project, the first Chinese trans-national gas pipeline, has been driving relations between Beijing and Astana. Kazakhstan indeed has extensive natural gas reserves, with 3 trillion cubic metres proven, and additional estimated reserves of 5 trillion cubic metres. While the country remains a small producer (27 billion cubic metres of gas in 2006), production is expected to increase to 40 billion cubic metres by 2010 and 80 billion cubic metres by around 2015, less than half of which will be required for domestic consumption. ${ }^{(103)}$ Concentrated in the west of the country (a quarter of the proven reserves are located in the Karachaganak gas fields), the Kazakh reserves could help supply the gas pipeline that Beijing negotiated with Turkmenistan in 2006, and would enable Astana to collect transit duty on Turkmen and Uzbek gas

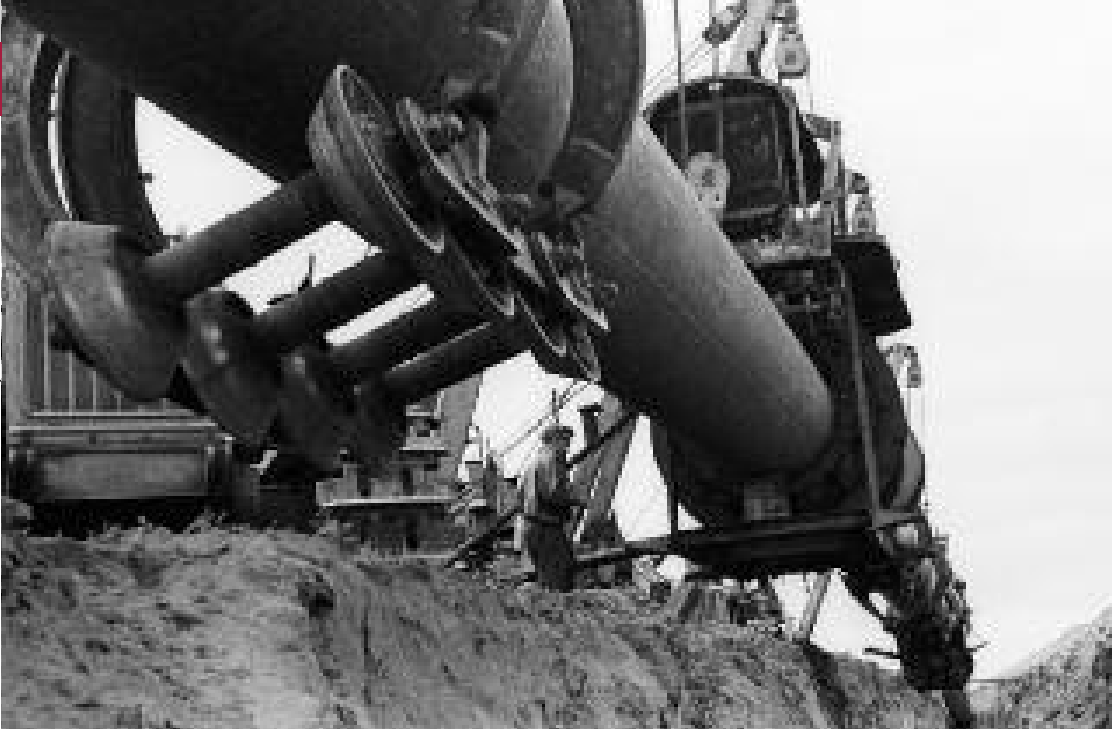

sent to China. ${ }^{(104)}$ Scheduled to be operational by the end of 2009, the Sino-Central Asian gas pipeline will have a capacity of 30 billion cubic metres per annum, with Kazakhstan, Uzbekistan, and Turkmenistan each supplying a third. ${ }^{(105)}$ PetroChina and the China National Oil and Gas Exploration and Development Corporation are each investing more than $\$ 2$ billion in the project.

Beginning at the Samandepe well, located near Bagtiyarlyk, on the right bank of the Amu-Daria, and reportedly containing 1.6 billion cubic metres of gas, the pipeline will cover only $180 \mathrm{~km}$ on Turkmen soil before crossing the Turkmenistan-Uzbekistan border at Gedaim. It will run for more than $500 \mathrm{~km}$ across Uzbekistan (the route has not yet been finalised) and for nearly 1,300 km across Kazakhstan, before reaching Xinjiang via Shymkent and Khorgos. On Kazakh soil, a section linking the Beyneu-Bozoy site to Chymkent via Kzyl-Orda could be constructed later. ${ }^{(106)}$ The Kazakh authorities hope by this means to aid supply to the country's southern regions, which are dependent on Uzbekistan and often under-supplied with gas during the winter months. The prospect of China-Kazakhstan cooperation in gas is not limited to these 10 billion cubic metres, however: the possibility of extending the pipeline's capacity so that it can carry a share of production from the immense

99. For further details, see Sébastien Peyrouse, "The Economic Aspects of the ChineseCentral Asia Rapprochement," op. cit., pp. 58-59, and Mekhmet Ogutchu, Ksin Ma, "Energeticheskaja geopolitika. Kitaj i Central'naja Azija" (The geopolitics of energy. China and Central Asia), Kazakhstan, no. 3, 2007, http://www.investkz.com/journals/52/498.html, consulted 15 August 2008.

100. Yitzhak Shichor, "China's Central Asian Strategy and the Xinjiang Connection: Predicaments and Medicaments in a Contemporary Perspective," op. cit., p. 70.

101. P. Sergeeva, "Atasu - Alashan'kou: vchera, segodnja, zavtra," op. cit.

102. Guo Xuetang, "The Energy Security in Central Eurasia: The Geopolitical Implications to China's Energy Strategy," The China and Eurasia Forum Quarterly, vol. 4, no. 4, 2006, pp. 117-137.

103. Mehmet Ögütçü, "Kazakhstan's Expanding Cross-Border Gas Links. Implications for Europe, Russia, China and other CIS countries," http://www.dundee.ac.uk/cepmlp/journal/html/Nol17/Nol17_8.pdf, consulted 19 August 2008.

104. Mekhmet Ogutchu, Ksin Ma, "Energeticheskaja geopolitika. Kitaj i Central'naja Azija," op. cit.

105. "Kazakhstan," Country Brief Analysis, Energy Information Administration, op. cit.

106. Jurij Sigov, "Kazakhstanskaja karta Pekina," Analytica, 2 December 2007, http://www.analitika.org/article.php?story=20071120020516946, consulted 18 August 2008. 
site of Karachaganak is mentioned regularly, causing concern in Gazprom. The Trans-Asia Gas Pipeline Company Ltd., created for this purpose, is working in collaboration with the national companies Turkmenneftegaz, Uzbekneftegaz, and KazMunayGaz. On 30 July 2008, KazMunayGaz and CNPC signed an agreement for construction and operation of a gas pipeline over the Kazakh section. ${ }^{(107)}$

\section{Kazakh concerns over Chinese energy domination}

China's presence in the Kazakh energy market is welcome: it reduces Russia's predominance and will enable the collection of transit rights on Uzbek and Turkmen gas, and even on Russian petroleum. In addition, the Chinese companies, supported by the political powers and their "good neighbour" policies, often grant contracts that are more favourable to KazMunayGaz than those of the large international consortiums. China's huge presence gives rise to concern, however, in some Kazakh political and economic circles. The internal operations of CNPC, which brings all its extraction equipment from China, pleases neither Kazakh entrepreneurs, who enjoy no benefit from increased sales, nor the trade unions, which criticise the foreign company's right to bring its own labour instead of providing employment to local workers. Some alarmist experts raise the threat of an enormous wave of Chinese migration that would affect the ethnic balance of sparsely populated Kazakhstan. ${ }^{(108)}$ The possibility that some regions could become economic enclaves entirely dependent on Chinese businesses is also a concern: the budget of the Kzyl-Orda region, for example, is reportedly funded 90 percent by taxes levied on the petroleum sector, which is dominated by Beijing. ${ }^{(109)}$

Debate on China's energy presence has reached the Parliament. In the autumn of 2006, following the acquisition of Nations Energy and the Karazhanbas site by the CITIC Group, several members of the Otan presidential party denounced "China's aggressive expansion in the petroleum sphere." ${ }^{(110)}$ During the debate, the elected member Valeri Kotovitch declared that the country was in the process of losing its energy independence, with China controlling, in his words, 28 percent of Kazakh petroleum production and set to obtain 40 percent of the market following acquisition of the MangistauMunayGaz company. The debate was so heated that Energy Minister Bakhytkozha Izmukhambetov, who said that China controlled only 12 percent of Kazakhstan's energy resources, ${ }^{(I I I)}$ was obliged to announce that he would do everything possible to block this takeover, which he ultimately failed to do. Nevertheless, early in 2007, the government of Kazakhstan passed a law prohibiting foreign companies from selling their exploitation licences to third parties within too short a timeframe, without state agreement.

The issue of Astana's lack of transparency in petroleum transactions regularly returns to the political stage. The Director of the Institute of the World Market, Alida Ashimbaeva, finds the lack of transparency in decisions on allocation of oil and gas deposits dangerous, and notes that China is abnormally favoured during the tendering process. ${ }^{(112)}$ Gulzhakhan Khadzhieva, a researcher at the Centre for Far-Eastern Studies at the Kazakh Institute of Oriental Studies, questions the future of the costly China-Kazakhstan pipeline if the price of petroleum plummets and if new deposits are discovered in the Tarim basin, ${ }^{(13)}$ while Konstantin Syroezhkin, of the Institute of Strategic Studies, questions the profitability of the pipeline without guarantees that Moscow will ship its petroleum through it. ${ }^{(114)}$ Meanwhile, Maria Disenova and Aytolkin Kurmanova, of the Institute of Economic Strategies, maintain that Beijing's ambitions in the oil and gas sector should not be underestimated, even if its investments occur through medium-sized sites. ${ }^{(115)}$

Environmental risk is also mentioned regularly. Furthermore, China's refusal to take account of expert archaeological assessments carried out along the route of the pipeline has resulted in the destruction of valuable prehistoric and ancient sites. ${ }^{(116)}$ The Kazakh government has kept a certain number of other fundamental questions shrouded in mystery, such as which country will be responsible for repair and security of the

107. "KazMunayGas, CNPC ink contract for Kazakhstan-China gas pipeline," Interfax China, 4 August 2008, http://www.interfax.cn/news/4545/, consulted 10 August 2008.

108. "Prisutstvie Kitaja v Kazakhstane: 'Dostizhenija' i 'perspektivy'," op. cit. 109. Ibid.

110. "Kitaem vedetsja bol'shaja rabota po priobreteniju rjada neftjanykh kompanij, rabotajushchikh v Kazakhstane" (China is undertaking a large program of acquisition of petroleum companies established in Kazakhstan), Nomad, 2 November 2006, http://www.nomad.su/?a=3-200611020217, consulted 19 August 2008.

111. Mekhmet Ogutchu, Ksin Ma, "Energeticheskaja geopolitika. Kitaj i Central'naja Azija," op. cit.

112. Alida Ashimbaeva, "Starye problemy novoj ekonomiki Kazakhstana," op. cit.

113. Gulzhakhan Khadzhieva, "Kazakhstan i Kitaj: strategicheskie podkhody k ekonomicheskomu sotrudnichestvu," op. cit.

114. Interview with Konstantin Syroezhkin, Almaty, 4 March 2008.

115. Maria Disenova, Aytolkin Kurmanova, "Neft' i gaz Kazakhstana - mjagkaja nacionalizacija ili smena partnerov?" (Kazakhstan's petroleum and gas: stealthy nationalisation or change of partners?), Oasis, 30 July 2007, www.ca-oasis.info/news/?c=1\&id=19422 consulted 12 August 2008.

116. Interview with Murat Auezov, Almaty, 10 March 2008. 
pipeline. ${ }^{(117)}$ The politician and intellectual Murat Auezov, a well-known opponent of President Nursultan Nazarbaev and a recognised China expert, is concerned over infringement on Kazakhstan's sovereignty if security is entrusted to Chinese companies rather than to the domestic forces of law and order. $\mathrm{He}$ and a number of other researchers believe that China's acquisition of these largely unprofitable oil and gas fields is motivated less by energy profits than by strategic interest, Beijing's objective being the development of a network in Kazakh territory that will legitimise its right of inspection over Astana in the event of political tensions. ${ }^{(118)}$

\section{Uranium and electricity: A growing area of China-Kazakhstan cooperation}

Kazakhstan's considerable uranium resources (almost 20 percent of known world resources, at between one and oneand-a-half million tonnes) are of great interest to China. More than 9,000 tonnes were extracted in 2008, and according to the forecasts of the Kazakhstan National Atomic Energy Agency Kazatomprom, the country could produce 18,000 tonnes of uranium by 2010 and 27,000 tonnes by 2015, and maintain this level until 2050. In 2001, Kazatomprom and the China National Nuclear Corporation (CNNC) commenced negotiations to create a joint venture for the export of Kazakh uranium to China. ${ }^{(119)}$ In the summer of 2004, the metallurgical plant of Ulbinsk, located at Ust-Kamenogorsk in the east of Kazakhstan, and owned by Kazatomprom, opened a subsidiary in Shanghai for the sale of beryllium, which is required for the enrichment of uranium. In November of that year, the two companies signed their first contract for the extraction of uranium, which will remain in force until 2020. ${ }^{(120)}$ The 2005 strategic cooperation treaty advocates the strengthening of ties between the two countries in the atomic energy sector and mentions "the unification of more segments of the industrial cycle for the production of enriched uranium." (21) In a further step, a new agreement was signed in December 2006 between Kazatomprom and the China Guangdong Nuclear Power Holding (CGNCP) for the supply by Astana of nuclear fuel to Chinese power stations. ${ }^{(122)}$ Within this framework, Kazakhstan sells China natural uranium, which China enriches before sending on to the Ulbinsk factory to be transformed into fuel. Negotiations have also taken place over joint exploitation of the Zhalpak uranium extraction site in southern Kazakhstan.

The last but not least element of China-Kazakhstan energy cooperation is the production of electricity. Unlike the hydro- carbon sector, Beijing's objective is not so much to transport this energy to the east of the country but rather to remedy the lack of supply in Xinjiang, and in the event of a surplus, to export electricity to countries in the south (Afghanistan, Pakistan, India). The strategic China-Kazakhstan partnership signed in 2005 provides for cooperation between the national electricity company of Kazakhstan, KEGOC, and China's GRID Corporation, and seeks the establishment of an "electricity bridge" between the two countries. ${ }^{(123)} \mathrm{A}$ first project valued at $\$ 10$ billion raises the prospect of the export of 40 billion $\mathrm{kw} / \mathrm{h}$ per annum produced in Kazakhstan, which would make Kazakhstan the largest exporter of electricity to China. However, the recurrent electricity deficit in Kazakhstan has prevented the project from becoming a reality, although it could come to fruition in a few years' time with the construction of a new power station at Ekibastuz and a $800 \mathrm{KW}$ high-voltage line.

Beijing would take full responsibility for funding its construction (at an estimated cost of $\$ 4.5$ billion, according to Chinese experts, or $\$ 7$ billion, according to their Kazakh colleagues), ${ }^{(124)}$ in exchange for which total output would be destined for China. It would be carried by a $4,000 \mathrm{~km}$ line linking Ekibastuz and Urumqi, then heading towards Xian or Wuhan. ${ }^{(125)}$ The former site of a gulag in the Pavlodar region, the town of Ekibastuz already contains the two largest coal-fired power stations in Kazakhstan, producing some 5,000 MW. ${ }^{(126)}$ Ekibastuz is considered the country's largest open cut coal mine and one of the richest in the

\section{Ibid.}

118. Ibid.

119. "Kazatomprom vedet peregovory o prodazhe Kitaju urana" (Kazatomprom is negotiating for the sale of uranium to China), BusinessPress, 24 August 2001 http://www.businesspress.ru/newspaper/article_mld_21960_ald_80147.html, consulted 4 April 2005.

120. "Jadernomu Kitaju nuzhen importnyj uran" (Nuclear China needs imported uranium), Iranatom.ru, September 2005, http://www.iranatom.ru/news/media/year05/september/chiur.htm, consulted 9 August 2008

121. Aleksander Shmidke, "Atomnaja promyshlennost' Kazakhstana: sovremennoe sostojanie i perspektivy razvitija," http://www.pircenter.org/data/publications/06-0531Shmidke_Article.pdf, consulted 5 August 2008.

122. "Kazatomprom pomozhet Kitaju" (Kazatomprom will assist China), Ekonomika i pravo, no. 12,2007, p. 4.

123. "Prisutstvie Kitaja v Kazakhstane: 'Dostizhenija' i 'perspektivy'," op. cit.

124. "Kazakhstan, China to jointly build large-scale power plant," People's Daily Online, 1 April 2006, http://english.people.com.cn/200604/01/eng20060401_255104.html, consulted 24 August 2008.

125. Sergej Smirnov, “'Kitajskie' megavatty” ('Chinese' megawatts), Ekspert Kazakhstan, http://www.expert.ru/printissues/kazakhstan/2007/32/kazahstanskiy_tek/, consulted 5 September 2008

126. "Joint-Stock Company 'Stantsiya Ekibastuz GRES-2' is preparing for large-scale measures aimed at boosting and upgrading the plant's performance," Interraoues, http://www.interrao.ru/eng/news/group/52/, consulted 26 August 2008. 
world, with reserves estimated at 13 billion tonnes. The new power station, with an expected output of 3,600 MW making it the CEI's most powerful, ${ }^{(127)}$ nevertheless poses serious environmental problems. Indeed, it would be a huge consumer of coal, which would only worsen the situation of what is already one of Kazakhstan's most polluted towns. In addition, the high-voltage line to China has no provision for connection to neighbouring Kazakh consumers, which implies that local residents will bear the ecological costs of the power station without receiving any of the benefits. The power station will thus increase Kazakhstan's export potential without remedying the internal consumption deficit. Once again, this situation has not been well received by Kazakhstan's political classes and experts, who see confirmation of their fears that Kazakhstan will be ruthlessly exploited by a China ravenous for raw materials. ${ }^{(128)}$

\section{Conclusion}

China has the capacity to inspire fear in Central Asia as elsewhere. Its energy presence is often overestimated in Kazakhstan, where the international consortiums Agip $\mathrm{KCO}$ and Tengizchevroil still control more than 65 percent of total hydrocarbon reserves. In the absence of Chinese involvement in the Tengiz and Kashagan sites, Beijing's share in the extraction of Kazakh petroleum is likely to decrease in tandem with the exploitation of the richest deposits. The China-Kazakhstan oil pipeline, capable of transporting 20 million tonnes of petroleum from the Caspian Sea to Xinjiang, clearly represents an important means of bypassing Russia, but will not shift Kazakh petroleum from its Russian orbit to a Chinese one, just as the China-Central Asia gas pipeline will not supercede Russia's dominance in the export of gas to Europe for several decades to come. The fear of China gaining an energy monopoly in Kazakhstan is thus exaggerated, as long as Russia and the major international groups remain well established there. On the other hand, it is likely that Kazakhstan will have to manage the growing tensions between Moscow and Beijing for control of the key sectors of hydrocarbons, uranium, gold, and electricity.

In economic terms, China outranks Russia only in the trade sector; the citizens of Kazakhstan find their daily living environment dominated by Chinese products, just as, in fact, citizens of the Russian Federation do. In the coming years, Kazakhstan will probably be forced to abandon industrial sectors that are becoming obsolete in the face of Chinese competition, and will see the disappearance of some sections of its economy, such as processing plants. This situation could prove problematic to social stability. Nevertheless, the development of Xinjiang and the likely formation of new free border trade zones confirms that the China-Kazakhstan trade dynamic brings more than it takes away from Kazakhstan. Indeed, Kazakhstan is achieving development in a less than propitious environment. Apart from China, and to a lesser extent Russia, Astana has no other markets among its neighbours: the rest of Central Asia is still affected by the post-Soviet economic crisis; Afghanistan's instability is holding back cooperation with India or Pakistan; and Iran and Turkey are not as well established as was thought at the beginning of the 1990s.

Moreover, a whole generation of young Kazakh entrepreneurs has grasped the fact that the country's future lies in its role as a transit point for Chinese goods to Russia and Europe, offering future generations a broad spectrum of jobs in the services sector. This strategic position could help maintain the country's dynamism in the event of a drop in the world price for hydrocarbons, on which Kazakhstan, like Russia, has too heavily based its economic development. As for the social problems caused by China's entry into the Kazakh market (corruption of officials - customs officials in particular - drain of capital, loss of intellectual capital redeployed to small business with immediate profits, etc.), the blame can not be placed on China when such problems have arisen in response to Astana's internal policies and the social change at work in Kazakhstan. The rise of China throughout Central Asia thus acts as a catalyst, revealing the dysfunction of local economies overly focused on raw materials and unattractive in other sectors, and exacerbating anxieties and phobias over the social changes experienced by these countries over the past two decades. •

\section{- Translated by Peter Brown}

127. "Prisutstvie Kitaja v Kazakhstane: 'Dostizhenija' i 'perspektivy'," op. cit. 128. Sergej Smirnov, “'Kitajskie' megavatty,” op. cit. 